Рекомендована д. біол. наук, профр. Л. С. Фірою

УДК 582.998.16:547466:543.544.5.0687

DOI 10.11603/2312-0967.2017.3.8123

\title{
ДОСЛІДЖЕННЯ АМІНОКИСЛОТНОГО СКЛАДУ АРТИШОКУ СУЦВІТЬ
}

\author{
(c) А. І. Федосов
}

\author{
Національний фрармацевтичний університет, Харків \\ fedosov.a@ukr.net
}

Мета роботи. Амінокислоти є одним із важливих компонентів комплексу біологічно активних речовин рослин. Амінокислоти містяться в рослинах у легкозасвоюваних комплексах і в біологічно доступних концентраціях для організму людини, що зумовлює вищу біодоступність і фрізіологічну активність порівняно з синтетичними аналогами. Тому метою роботи було дослідження амінокислотного складу артишоку суцвіть.

Матеріали і методи. Визначення вільних та зв'язаних амінокислот проводили методом високоефективної рідинної хроматограсрії (BEPX). Хроматографрічне розділення здійснювали на рідинному хроматографрi Agilent 1200 (Agilent technologies, USA). Ідентисрікацію амінокислот проводили шляхом порівняння часів утримання 3 сумішшю стандартів амінокислот.

Результати й обговорення. Методом високоефрективної рідинної хроматографії у артишоку суцвіттях було ідентифріковано та визначено вміст 14 амінокислот, серед яких 13 визначено як у вільному стані, так і зв'язаному, а тирозин виявлено лише у зв'язаному стані. Як показали результати проведених досліджень, серед вільних амінокислот найбільше міститься проліну - 2,21 \% і аспарагінової кислоти - 1,23 \%, у зв'язаному стані у великій кількості накопичуються аспарагінова кислота (14,44 \%) і глутамінова кислота (5,22 \%). Тирозин у вільному стані в артишоку суцвіттях не виявлено.

Висновки. Методом високоефективної рідинної хроматографії досліджено амінокислотний склад артишоку суцвіть.

Ключові слова: артишок посівний; замінні амінокислоти; незамінні амінокислоти; високоефективна рідинна хроматограсрія.

Вступ. Амінокислоти містяться в рослинах у легкозасвоюваних комплексах та у біологічно доступних концентраціях для організму людини, що зумовлює вищу біодоступність і фрізіологічну активність порівняно з синтетичними аналогами [1, 2]. В організмі людини амінокислоти, окрім утворення молекул білків, виконують ще ряд важливих фрункцій: беруть участь у синтезі амінокислот; входять до складу різних природних сполук косерментів, жовчних кислот, антибіотиків; беруть участь в утворенні гормонів, медіаторів і нейротрансмітерів; є джерелами метаболітів, які беруть участь в обміні речовин [3, 4]. Детальний аналіз біохімічних властивостей і фрункцій різних амінокислот здійснено у ряді ґрунтовних наукових досліджень [5-7], хоча їх дія на людський організм залежно від дози і поєднання в амінокислотному комплексі залишається актуальною.

Метою роботи було дослідження амінокислотного складу артишоку суцвіть.

$\begin{array}{cc}\text { Час, хв } & \text { Рухома фраза } \mathrm{A}(\% \text { об/об) } \\ 0-2 & 100 \\ 2-18 & 100 \rightarrow 43 \\ 18-19 & 43 \rightarrow 0 \\ 19-22 & 0 \\ 22-23 & 0 \rightarrow 100 \\ 23-26 & 100\end{array}$

Матеріали і методи. Визначення вільних та зв'язаних амінокислот у артишоку суцвіттях проводили методом ВЕРХ. Метод оснований на екстракції вільних амінокислот із рослинної сировини, з подальшим кислотним гідролізом рослинних препаратів та наступним аналізом гідролізатів методом ВЕРX із передколонковою дериватизацією 9-срлуоренілметоксикарбоніл хлоридом (FMOC) та о-срталевим альдегідом (OPA) 3 наступною детекцією фрлуоресцентим детектором.

Хроматограсрічне розділення проводили на рідинному хроматографрі Agilent 1200 (Agilent technologies, USA). Колонка Zorbax AAA завдовжки 150 мм, внутрішнім діаметром 4,6 мм, діаметр зерна сорбенту 3 мкм, температура термостату колонки $40^{\circ} \mathrm{C}$. Мобільна фраза А - 40 ммоль/л $\mathrm{Na}_{2} \mathrm{HPO}_{4}$ при рН 7.8; мобільна фраза В - ацетонітрил : метанол : вода (45:45:10, V/V/V). Режим елюювання градієнтний за схемою, наведеною нижче.

Рухома фраза В (\% об/об)
0
$0 \rightarrow 57$
$57 \rightarrow 100$
100
$100 \rightarrow 0$
0

ISSN 2312-0967. Pharmaceutical review. 2017. № 3 
Фітохімічні дослідження

Phytochemical researches

В процесі хроматографрування детектування здійснювали у наступному режимі:

$$
\begin{gathered}
\text { Час, хв } \\
0 \rightarrow 15 \\
15 \rightarrow 26
\end{gathered}
$$

Довжина хвилі збудження, нм

340

266
Довжина хвилі випромінювання (емісії/детектування), нм

450

305
Для екстракції вільних амінокислот наважку препарату поміщали у віалу, додавали водний 0,1 моль/л розчин кислоти хлористоводневої та витримували на ультразвуковій бані при $50{ }^{\circ} \mathrm{C}$ протягом 3 год. Для екстракції суми вільних і зв'язаних амінокислот наважку препарату поміщали у віалу, додавали водний 6 моль/л розчин кислоти хлористоводневої та поміщали в термостат при $110{ }^{\circ} \mathrm{C}$. Гідроліз проводили протягом 24 год. 0,5 мл відцентрисругованого екстракту/гідролізату упарювали на роторному випарювачі, тричі промиваючи водою очищеною для видалення кислоти хлористоводневої. Ресуспендували залишок в 0,5 мл води очищеної та фрільтрували крізь мембранні фрільтри із регенерованої целюлози 3 порами 0,2 мкм. Одержання фрлуоресцентних похідних амінокислот здійснювали в автоматичному програмованому режимі перед введенням проби в хроматографрічну колонку.

Ідентифрікацію амінокислот проводили шляхом порівняння часів утримування піків на хроматограмі випробовуваного розчину з часами утримування речовин - стандартів амінокислот на хроматограмі розчину порівняння. Вміст зв'язаних амінокислот визначали шляхом віднімання вмісту вільних амінокислот від їх загального вмісту.

Розрахунок вмісту амінокислот (X, мкг/мг) проводили за фрормулою:

$$
X=\frac{C \cdot V_{\text {розч }}}{m_{\text {npen }}},
$$

де C - концентрація в мкг/мл, отримана із розрахунку за хроматограмами розчину порівняння і випробовуваного розчину; $\mathrm{V}_{\text {розч }}$ - об'єм розчинника для екстракції, мл; $m_{\text {преп }}$ - наважка препарату, мг [8-13].

Результати й обговорення. Зразки хроматограм, отримані при визначенні вмісту амінокислот в артишоку суцвіттях, наведено на рисунках 1 і 2, а результати визначення в таблиці 1.

Як видно з даних рисунків 1 і 2 та результатів, наведених у таблиці 1, в артишоку суцвіттях було ідентифріковано 14 амінокислот, 13 з яких перебували як у вільному стані, так зв'язаному, і а тирозин -тільки у зв'язаному. Серед вільних амінокислот найбільше містилося проліну - 2,21 \% і аспарагінової кислоти 1,23 \%. У зв'язаному стані у великій кількості накопичуються аспарагінова кислота $(14,44 \%)$ і глутамінова кислота (5,22 \%).

Аспарагінова кислота забезпечує перетворення вуглеводів в енергію м'язів, підвищує активність імунної системи, підвищує опірність до втомлюваності, зберігає здатність до роботи та витривалість,

\begin{tabular}{|c|c|c|c|c|}
\hline \multirow{2}{*}{ Час утримання, хв } & \multirow{2}{*}{ Амінокислота } & \multicolumn{3}{|c|}{ Вміст амінокисислот, \% } \\
\hline & & сума & вільні & зв'язані \\
\hline 1,62 & Аспарагінова кислота & 15,67 & 1,23 & 14,44 \\
\hline 2,78 & Глутамінова кислота & 5,45 & 0,23 & 5,22 \\
\hline 6,00 & Серин & 2,11 & 0,24 & 1,87 \\
\hline 7,12 & Гістидин & 1,11 & 0,15 & 0,96 \\
\hline 7,40 & Гліцин & 2,34 & 0,06 & 2,29 \\
\hline 7,68 & Треонін & 1,91 & 0,08 & 1,83 \\
\hline 8,71 & Аргінін & 2,15 & 0,25 & 1,90 \\
\hline 9,11 & Аланін & 2,61 & 0,31 & 2,30 \\
\hline 10,54 & Тирозин & 1,03 & - & 1,03 \\
\hline 12,74 & Валін & 2,26 & 0,12 & 2,13 \\
\hline 14,36 & Фенілаланін & 2,33 & 0,09 & 2,24 \\
\hline 14,53 & Ізолейцин & 2,31 & 0,04 & 2,26 \\
\hline 15,32 & Лейцин & 3,25 & 0,01 & 3,24 \\
\hline 19,85 & Пролін & 2,24 & 2,21 & 0,02 \\
\hline
\end{tabular}
має гепатопротекторні властивості, бере участь у реакціях циклу сечовини та переамінування, синтезі

Таблиця 1. Результати вивчення амінокислотного складу артишоку суцвіть

ISSN 2312-0967. Фармацевтичний часопис. 2017. № 3 


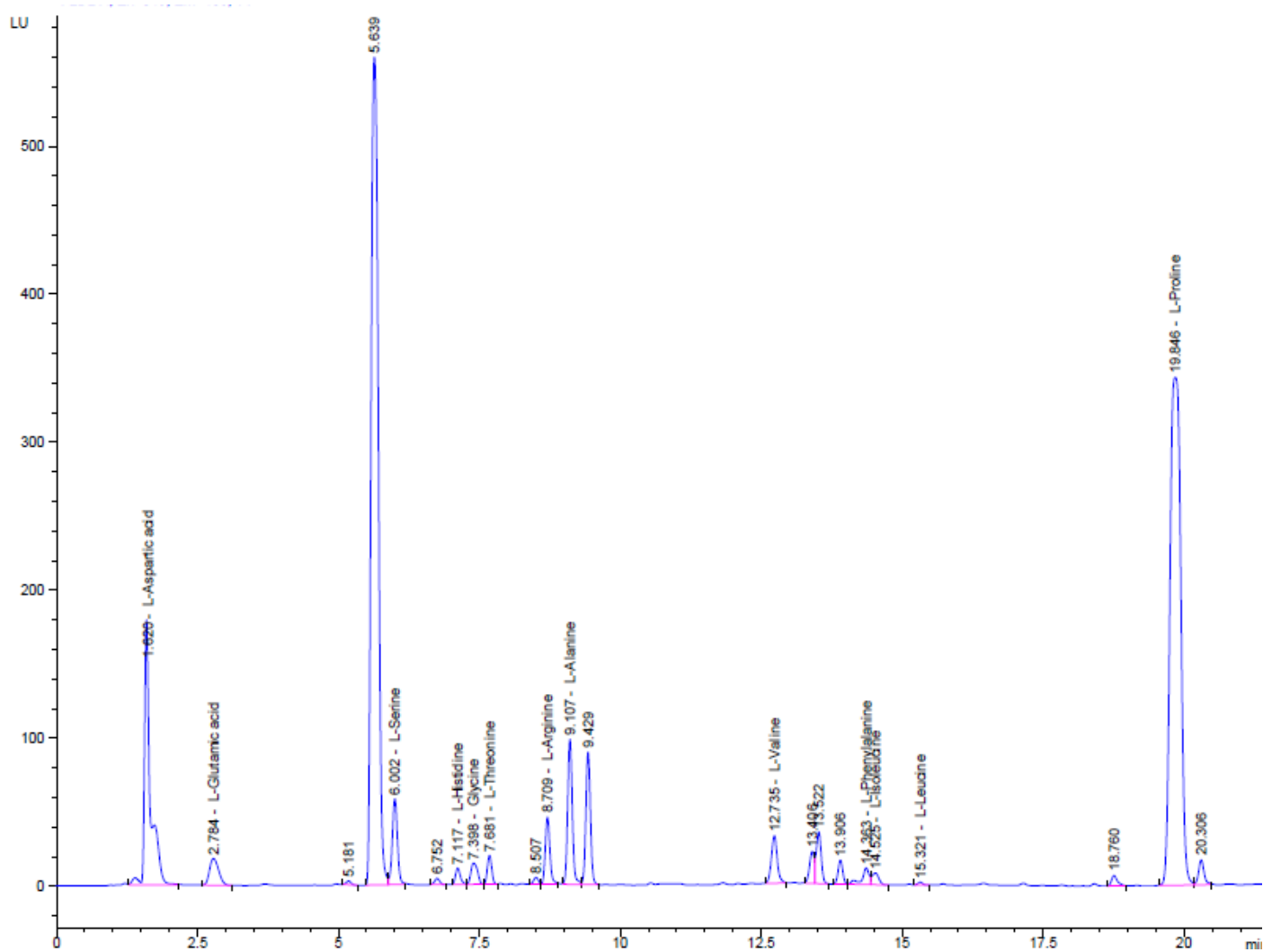

Рис. 1. ВEPX хроматограма, отримана в умовах визначення вільних амінокислот в артишоку суцвіттях

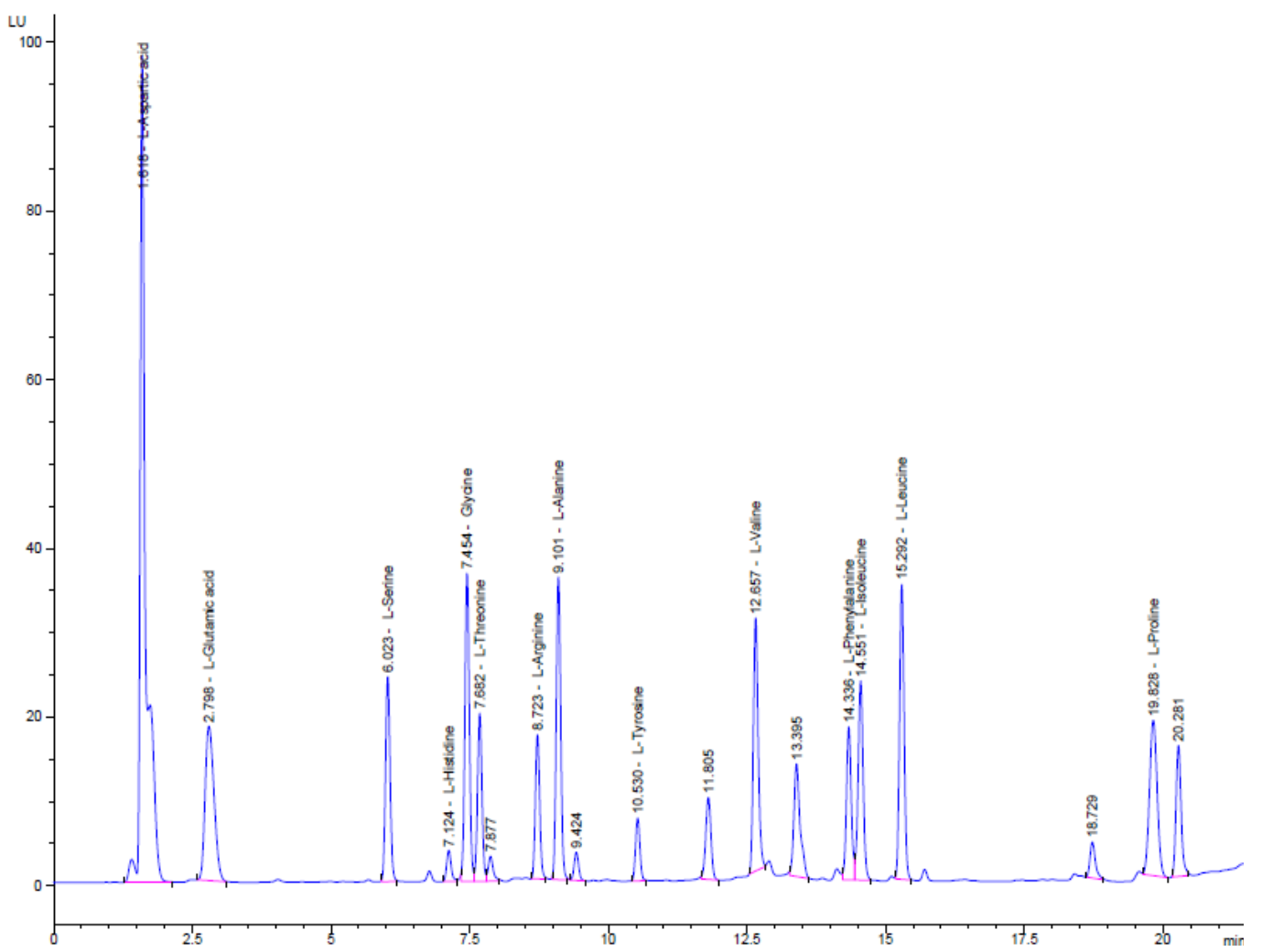

Рис. 2. ВEPХ хроматограма, отримана в умовах визначення суми вільних і зв'язаних амінокислот в артишоку суцвіттях.

ISSN 2312-0967. Pharmaceutical review. 2017. № 3 
метіоніну, треоніну і лізину. Аспарагін здатний зв'язувати аміак у тканинах; підтримує нормальне функціонування нервової системи, печінки; перешкоджає як надмірному збудженню, так і зайвому гальмуванню; бере участь у метаболічних процесах; стимулює імунітет [7].

Пролін $є$ головним компонентом колагену; сприяє загоєнню ран, опіків, виразок, доброму функціонуванню суглобів; захищає стінки судин; зміцнює сухожилля, зв'язки та серцевий м'яз; бере участь в утворенні адреналіну; зменшує запалення шкіри та слизових оболонок; поліпшує структуру шкіри; підтримує нормальний стан сполучних тканин печінки, нирок, склери ока, судин; покращує здатність до навчання [7].

Глутамінова кислота бере участь у білковому обміні, підтримує дихання клітин головного мозку, кис- лотно-лужний гомеостаз у крові та тканин [3]. Вона $€$ попередником синтезу орнітину і проліну, сприяє тимчасовому знешкодженню аміаку з утворенням нетоксичного глутаміну [5].

Висновки. Методом високоефективної рідинної хроматографії проведено вивчення амінокислотного складу артишоку суцвіть.

У артишоку суцвіттях було ідентифріковано 14 амінокислот, серед яких 13 виявляються як у вільному, так і в зв'язаному стані, а тирозин виявлено лише у зв'язаному стані; визначено кількісний вміст кожної ідентифікованої амінокислоти. Серед вільних амінокислот найбільше містилося проліну - 2,21 \% і аспарагінової кислотаи- 1,23 \%; у зв'язаному - аспарагінова кислота (14,44 \%) і глутамінова кислота $(5,22 \%)$.

\title{
ИССЛЕДОВАНИЕ АМИНОКИСЛОТНОГО СОСТАВА АРТИШОКА СОЦВЕТИЙ
}

\section{А. И. Федосов}

\author{
Национальный фрармацевтический университет, Харьков \\ fedosov.a@ukr.net
}

Цель работы. Аминокислоты являются одним из важных компонентов комплекса биологически активных веществ растений. Аминокислоты содержатся в растениях в легко усваиваемых комплексах и в биологически доступных концентрациях для организма человека, что обуславливает высокую биодоступность и фризиологическую активность в сравнении с синтетическими аналогами. Поэтому целью работы было исследование аминокислотного состава артишока соцветий.

Материалы и методы. Определение свободных и связанных аминокислот проводили методом высокоэффективной жидкостной хроматографии (ВЭЖХ). Хроматограсрическое разделение осуществляли на жидкостном хроматографре Agilent 1200 (Agilent technologies, USA). Идентификацию аминокислот проводили путем сравнения время удерживания со смесью стандартов аминокислот.

Результаты и обсуждение. Методом высокоэффективной жидкостной хроматографии в артишока соцветиях было идентифицировано и определено содержание 14 аминокислот, среди которых 13 обнаружены как в свободном так и в связанном виде, а тирозин только в связанном виде. Как показали результаты проведенных исследований, среди свободных аминокислот в большом количестве содержатся пролин - 2,21 \% и аспарагиновая кислота - 1,23 \%, в связанном состоянии в большом количестве накапливаются аспарагиновая кислота $(14,44 \%)$ и глютаминовая кислота (5,22 \%).

Выводы. Методом высокоэфффективной жидкостной хроматографии исследован аминокислотный состав артишока соцветий.

Ключевые слова: артишокпосевной; заменимые аминокислоты; незаменимые аминокислоты; высокоэфффективная жидкостная хроматограсия.

\section{AMINO ACID COMPOSITION OF ARTICHOKE INFLORESCENCE}

\section{A. I. Fedosov}

National University of Pharmacy, Kharkiv

fedosov.a@ukr.net

The aim of the work. Amino acids comprise one of the important components of biologically active compounds in plants. Amino acids are present in plants in highly digestible complexes and in biologically available concentrations for the human body which provides higher bioavailability and physiological activity comparing to synthetic analogues. Thus, the purpose of current work was to study the amino acid composition of artichoke inflorescences.

ISSN 2312-0967. Фармацевтичний часопис. 2017. № 3 
Materials and Methods. Free and bound amino acids were analyzed using the high-performance liquid chromatography (HPLC) method. The chromatographic separation was carried out by the eans of liquid chromatograph Agilent 1200 (Agilent technologies, USA). The amino acids were identified by comparing retention time with the mixture of amino acids' standard samples.

Results and Discussion. 13 free and 14 bound amino acids were identified and quantified in artichoke inflorescences by the means of HPLC. As the results of the experiments have shown, proline (2.21\%) and aspartic acid (1.23 \%) dominated among the free amino acids, while aspartic acid (14.44 \%) and glutamic acid (5.22\%) were accumulated in high amounts in bound state.

Conclusions. The amino acid composition of artichoke inflorescences was studied using the HPLC technique.

Key words: artichoke; non-essential amino acids; essential amino acids; high-performance liquid chromatography.

\section{Список літератури}

1. Ісюк М. В. Дослідження амінокислотного складу герані сибірської / М. В. Ісюк, І. Л. Бензель, Л. В. Бензель // Актуальні пит. фрармацевт. і мед. науки та практ. - 2012. - № 3 (10). - С. 4-6.

2. Делян Є. П. Амінокислотний склад надземних органів рослин роду Sonchus / Є. П. Делян // Фармакол. та лік. токсикол. - 2016. - № 1 (47). - С. 102-106.

3. Лысиков Ю. А. Аминокислоты в питании человека / Ю. А. Лысиков // Экспериментал. и клинич. гастроентеролог. - 2012. - № 2. - С. 88-105.

4. Смирнов В. А. Аминокислоты и полипептиды : учеб. пособ. Ч. І. / В. А. Смирнов, Ю. Н. Климочкин. - Самара : Самар. гос. техн. ун-т., 2007. - 110 с.

5. Фармацевтична енциклопедія / Гол. ред. Ради та автор передмови В. П. Черних. - 3-тє вид., переробл. і доповн. - К. : «МОРІОН», 2016. - 1952 с.

6. Аминокислоты глазами химиков, фрармацевтов, биологов : в 2-х т. Том 2 / Сыровая А. О., Шаповал Л. Г., Макаров В. А. [и др.] - Х. : «Щедра садиба плюс», 2015. -268 c.

7. Аминокислоты глазами химиков, фрармацевтов, биологов : в 2-х т. Том 1 / Сыровая А. О., Шаповал Л. Г., Макаров В. А. [и др.] - Х. : «Щедра садиба плюс», 2014 $-228 \mathrm{c}$.

8. Henderson J. W. Rapid, accurate, sensitive, and reproducible HPLC analysis of amino acids, amino acid analysis

\section{References}

1. Isyuk MV, Benzel IL, Benzel LV. [Doslidzhennia aminokyslotnoho skladu herani sybirskoi] Aktualni pyt farmatsevt i med. nauky ta prakt. 2012;3(10): 4-6. Ukrainian.

2. Delyan YeP. [Aminokyslotnyy sklad nadzemnykh orhaniv roslyn rodu Sonchus] Farmakol ta lik toksykol 2016;1(47): 102-106. Ukrainian.

3. Lysikov YuA. [Aminokisloty v pitanii cheloveka] Eksperimental. i klinich. gastroenterolog. 2012;2: 88-105. Russian. 4. Smirnov VA, Klimochkin YuN. Aminokisloty i polipeptidy : ucheb. posob. Ch. I. [Аминокислоты и полипептиды : учеб. пособ. ч. І.] Samara: Samara State Technical University; 2007. Russian.

5. Farmatsevtychna entsyklopediya [Фармацевтична енциклопедія] / Hol. red. Rady ta avtor peredmovy V. P. Chernykh. Kyyiv: MORION; 2016. Ukrainian. using Zorbax Eclipse-AAA columns and the Agilent 1100 HPLC / J. W. Henderson, R. D. Ricker, B. A. Bidlingmeyer [et al.] // Agilent Technical Note. - 1999. - P. 5980-1193E.

9. Jámbor A. Quantitation of amino acids in plasma by high performance liquid chromatography: Simultaneous deproteinization and derivatization with 9-fluorenylmethyloxycarbonyl chloride / A. Jámbor, I. Molnár-Perl // J. Chromatogr. A. - 2009. - P. 6218-6223.

10. Jámbor A. Amino acid analysis by high-performance liquid chromatography after derivatization with 9-fluorenylmethyloxycarbonyl chloride. Literature overview and further study / A. Jámbor, I. Molnár-Perl // J. Chromatogr. A. - 2009. - P. 3064-3077.

11. Popyk A. The carbohydrates and aminoacids study in common lilac of Charles Joile variety flowers and leaves / A. Popyk, V. Kyslychenko, V. Korol [et al.] // American Journal of Science and Technologies. - 2015. - №2 (20). - C. 779-785.

12. Вивчення амінокислотного складу трави десмодіуму канадського сорту Persei / Д. О. Мезенцев, В. С. Кисличенко, Н. Є. Бурда [та ін.] // ScienceRise. Фармацевтичні науки. - 2016. - №3(3). - С. 13-15.

13. Порівняльне вивчення амінокислотного та мінерального складу листя Prunus persica, заготовленого в Таджикистані та Україні / Г. Ф. Наврузова, Л. В. Ленчик, В. С. Кисличенко [та ін.] // Фармацевт. часоп. - 2016. № 1. - C. 30-33.

6. Syrovaya AO, Shapoval LG, Makarov VA, Petyunina VN, Graboveckaya ER, Andreeva SV, Nakonechnaya SA, Bachinskij RO, Luk'yanova LV, Kozub SN, Levashova OL. Aminokisloty glazami himikov, farmacevtov, biologov: $v$ 2-h t. T. 2 [Аминокислоты глазами химиков, фрармацевтов, биологов : в 2-х т. Т. 2] Kharkov: Shchedra sadiba plyus; 2015. Russian.

7. Syrovaya AO, Shapoval LG, Makarov VA, Petyunina VN, Graboveckaya ER, Andreeva SV, Nakonechnaya SA, Bachinskij RO, Luk'yanova LV, Kozub SN, Levashova OL. Aminokisloty glazami himikov, farmacevtov, biologov: v 2-h t. T. 1 [Аминокислоты глазами химиков, фрармацевтов, биологов : в 2-х т. Т. 1] Kharkov: Shchedra sadiba plyus; 2014. Russian.

8. Henderson JW, Ricker RD, Bidlingmeyer BA, Woodward C. Rapid, Accurate, Sensitive, and Reproducible

ISSN 2312-0967. Pharmaceutical review. 2017. № 3 
HPLC Analysis of Amino Acids Amino Acid Analysis Using Zorbax Eclipse-AAA Columns and the Agilent 1100 HPLC. Agilent Technical Note, 1999; 5980-1193E.

9. Jámbor A, Molnár-Perl I. Quantitation of aminoacids in plasma by high performance liquid chromatography: Simultaneous deproteinization and derivatization with 9-fluorenylmethyloxycarbonyl chloride. J. Chromatogr. A. 2009: 6218-6223.

10. Jámbor A, Molnár-Perl I. Aminoacid analysis by highperformance liquid chromatography after derivatization with 9-fluorenylmethyloxycarbonyl chloride. Literature overview and further study. J. Chromatogr. A. 2009: 3064-3077.
11. Popyk A, Kyslychenko V, Korol V, Gurieva I. The carbohydrates and aminoacids study in common lilac of Charles Joile variety flowers and leaves. American Journal of Science and Technologies. 2015;2(20): 779-785.

12. Mezentsev DO, Kyslychenko VS, Burda NYe, D'yakonova YaV. [Vyvchennya aminokyslotnoho skladu travy desmodiumu kanadskoho sortu Persei] ScienceRise. Farmatsevtychni nauky. 2016;3(3): 13-15. Ukrainian.

13. Navruzova HF, Lenchyk LV, Kyslychenko VS, Sharyfov KhSh, D'yakonova YaV. [Porivnyalne vyvchennia aminokyslotnoho ta mineral'noho skladu lystya Prunus persica, zahotovlenoho $v$ Tadzhykystani ta Ukraini] Farmatsevt. chasop. 2016;1: 30-33. 